\title{
Impact of Organic and Inorganic Nutrient Management Practices on Flowering, Corm Traits and Profitability of Gladiolus Hybrids
}

\author{
Kishan Swaroop* and V.K. Sharma \\ Division of Floriculture and Landscaping, ICAR-Indian Agricultural \\ Research Institute-110012, India \\ *Corresponding author
}

\section{A B S T R A C T}

\begin{tabular}{l}
\hline Ke y w o r d s \\
Gladiolus, Hybrids, \\
Net returns, \\
Organic, Inorganic, \\
$\begin{array}{l}\text { Flowering and } \\
\text { Corm traits }\end{array}$ \\
\hline Article Info \\
\hline $\begin{array}{l}\text { Accepted: } \\
\text { 26 July 2020 } \\
\text { Available Online: } \\
\text { 10 August } 2020\end{array}$ \\
\hline
\end{tabular}

\section{Introduction}

Gladiolus is an important bulbous flower grown throughout the world. It is originated from South Africa and belongs to the family Iridaceae. It is also ideal both for garden display and floral arrangements for table and interior decoration as well as making high quality bouquet (Lepcha et al., 2007). The main emphasis in gladiolus improvement has been on development of varieties having attractive colour and large number of florets mainly for cut flower, long spikes, more number of well-spaced large sized florets, and good corm multiplication ability. Gladiolus is very rich in varietal wealth and every year there is an addition of new varieties (Rajiv Kumar and Yadav, 2005). These varieties 
require more nutrients for higher growth, production and quality of flowers.

The Integrated nutrient management (INM) is an approach to ensure the desired flower crop productivity through optimization of various plant nutrients in an integrated manner. INM adopts a holistic view of plant nutrient management by considering the totality of the farm resources that can be used as plant nutrients. The use of organic manures and bio-fertilizers along with the balance use of chemical fertilizers is known to improve physicochemical and biological properties of soil, besides improving the efficiency of applied fertilizers. The objective of INM is to optimize the use of all available resources of plant nutrients for higher crop productivity without impairing the inherent soil fertility. If in the past, the emphasis was on increased use of fertilizer; the current approach should aim on educating farmers to optimize use of organic, inorganic and biological fertilizer in an integrated way. In recent years, integrated use of inorganic and organic manures has become important for higher agricultural produce as no single source of plant nutrients, either it is chemical, organic or bio fertilizers can meet the entire needs of crop. Plant nutrition today requires judicious and integrated management of all sources of nutrients with the objective of sustaining high yields over years without deteriorating/ impairing the soil health in any respect. Use of organic manures in INM helps in mitigating multiple nutrient deficiency (Kanaujia et al., 2018).

The yield and quality of flowers and corms can be improved by adopting integrated nutrient management practices which include the judicious and combined use of organic, inorganic and bio-fertilizers (Singh et al., 2006). Multiplication of planting material of gladiolus is most important, because the cut flower trade of gladiolus is lagging behind over the recent years, owing to the unavailability of sufficient quality planting material at large scale (Barman et al., 2005). Farmers are using chemical fertilizers unscrupulously which are costly and create threat to soil health, ultimately leading to health hazards in human beings. Moreover, this is not sustainable approach; instead it is fiery to get more spikes and corm yield. Wani et al., (1917) also advocated that by reducing the levels of chemical fertilizer and optimizing the dose of different organic fertilizer can improve yield and quality in ornamental crops without adversely affecting the edaphic and environmental features. So, there is a need to develop sustainable production system, where in chemical fertilizers can be minimized by using alternative sources of nutrients such as organic and bio-fertilizers which is supplement nutritional requirement of gladiolus crop. Integrated application of inorganic fertilizers, organic manures and biological sources of nutrients in an efficient way would not only reduce the sole dependence on inorganic fertilizers, but also enhances the productivity as well as minimizing environmental hazards. Integrated Nutrient Management concept is one of the eco-friendly approaches. Although biofertilizers are not an alternative to inorganic fertilizers, they may be useful in increasing the yield and quality of flowers when they are combined with organic manures and inorganic fertilizers in balanced proportion. Keeping the above said facts in view, the present investigation has been planned to study the integrated nutrient management by using organic manures, bio-fertilizers and inorganic fertilizers in gladiolus hybrids for flower traits and corm production.

\section{Materials and Methods}

The field experiment was carried out over a two year period from 2016-17 to 2017-18 at 
the Research Farm of the Division of Floriculture and Landscaping, ICAR-Indian Agricultural Research Institute, New Delhi. The experiment was laid out in split plot design with three replications, at a spacing of $50 \mathrm{~cm} \times 10 \mathrm{~cm}$ at $6-8 \mathrm{~cm}$ depth in a plot size of $2.00 \mathrm{~m} \mathrm{x} 2.00 \mathrm{~m}$. The experiment was conducted in loam soil with $\mathrm{pH}$ 8.3. Well decomposed farmyard manure, Vermicompost, Azospirillum, PSB and liquid NPK were applied treatment-wise before planting. Recommended fertilizer doses of 200:100:100 kg/ha NPK were also given treatment-wise as $125 \%, 100 \%, 75 \%$ and $50 \%$. These fertilizers were applied in the form of Urea, Single super phosphate and Muriate of potash. Uniform size of gladiolus corms (4.0 to $5.0 \mathrm{~cm}$ ) of hybrids Melody Open Seedling and P-16-1 x Eurovision were planted in the month of October during both the year. The gladiolus hybrids were treated as main plot factor while INM treatments were treated as sub-plot factor. The treatments imposed were : $\mathrm{T}_{1}$ : Control, $\mathrm{T}_{2}: 75 \% \mathrm{RDF}$, $\mathrm{T}_{3}: 100 \%$ RDF (200:100:100 kg/ha NPK), $\mathrm{T}_{4}$ : FYM@10 t/ha, $T_{5}$ : Vermicompost@10 t/ha, $\mathrm{T}_{6}: 100 \% \mathrm{RDF}+\mathrm{FYM} @ 5 \mathrm{t} / \mathrm{ha}, \mathrm{T}_{7}$ : 100\% RDF + Vermicompost @ $5 \mathrm{t} / \mathrm{ha}, \mathrm{T}_{8}$ : $125 \% \mathrm{RDF}+$ Azospirillum + PSB, $\mathrm{T}_{9}: 75 \%$ $\mathrm{RDF}+\mathrm{FYM} @ 10 \mathrm{t} / \mathrm{ha}+$ Azospirillum + $\mathrm{PSB}, \mathrm{T}_{10}: 75 \% \mathrm{RDF}+$ Vermicompost @ 10 t/ha + Azospirillum +PSB, $\mathrm{T}_{11}: 75 \% \mathrm{RDF}+$ FYM@ 5 t/ha + Vermicompost@ 5 t/ha + Azospirillum + PSB, and $\mathrm{T}_{12}: 50 \% \mathrm{RDF}$ +FYM@5t/ha +Vermicompost @ 5 t/ha + liquid NPK. The entire dose of Single super phosphate and Muriate of potash and half dose of Urea was applied before planting and incorporated in the field uniformly. The remaining half dose of Urea was top dressed after one month of planting. Irrigation was given immediately after planting and thereafter adequate soil moisture was maintained in the soil by giving regular irrigation from time to time. Plots were kept weed free by hand weeding. Disease control measures were taken up by spraying fungicides such as Bavistin, Captan or M-45 whenever necessary throughout the experiment to grow a healthy crop. Other uniform agronomic practices were followed as and when required. Data for various vegetative and flowering and corm parameters were recorded at appropriate time after planting and analyzed by "analysis of variance" techniques as suggested by Panse and Sukhatme (1967).

\section{Results and Discussion}

The two year mean data revealed that application of organic, inorganic and bio fertilizers had produced significant effect on vegetative and corm production parameters viz., days to first flowering, plant height, spike length, number of florets per spike, number of marketable spikes and number of corms per hectare. The data indicated that between two hybrids, P-16-1 x Eurovision had taken minimum 85.75 and 88.50 days respectively during both years while the hybrid Melody Open Seedling had taken maximum 89.58 and 92.50 days during the 2016-17 and 2017-18 respectively. Further, the examination of experimental finding showed that different treatment of organic, inorganic and bio-fertilizers exerted significant effect on days to first flowering during the year 2016-17, 2017-18 and mean. The treatment $\mathrm{T}_{6}(100 \% \mathrm{RDF}+\mathrm{FYM} @ 5$ $\mathrm{t} / \mathrm{ha}$ ) in which average mean of both hybrids observed as 84.50 days and treatment $\mathrm{T}_{7}$ was also at par during first year, but during second year, treatment $\mathrm{T}_{2}$ i.e. application of $75 \%$ RDF had taken minimum days (86.00). The data presented in table 1 revealed that the interaction effect of hybrids and integrated nutrient management treatments were also found significant with respect to days to first flowering during both the year and data indicated that the hybrid P-16-1 x Eurovision had taken minimum days (84.00) during first 
year with the application of FYM @ 10 t/ha, while during second year, it was 79.00 days in the same hybrid with the application of $75 \%$ RDF. The variation in plant height and spike length between the two hybrids was significantly influenced by different treatments of organic, inorganic and biofertilizers during the year 2016-17, 2017-18 and mean which presented in table 2 and 3 . Among the hybrids, average maximum plant height $(111.50 \mathrm{~cm}$ and $108.16 \mathrm{~cm})$ was recorded in Melody Open Seedling which was significantly lengthier than the P-16-1 $x$ Eurovision hybrid during both the year. The effect of different treatment of organic, inorganic and bio-fertilizers on plant height differed significantly during the year 2016-17, 2017-18 and mean of two hybrids during the year 2016-17 and data indicated the maximum plant height $(124.50 \mathrm{~cm})$ in the treatment $\mathrm{T}_{6}$ i.e. application of $100 \% \mathrm{RDF}+$ FYM @ 5 t/ha while during the year 2017-18, it was recorded maximum $(117.50 \mathrm{~cm})$ in the treatment $\mathrm{T}_{12}$ i.e. $50 \% \mathrm{RDF}+\mathrm{FYM} @ 5$ t/ha +Vermicompost@5 t/ha + liquid NPK. Significant variation was also observed for spike length and mean of two year showed maximum spike length $(100.91 \mathrm{~cm}$ and 98.16 $\mathrm{cm})$ respectively in Melody Open Seedling hybrid. The effect of different integrated nutrient management treatment on spike length was significant during both year and it is cleared from the data presented in table 3 revealed that treatment $\mathrm{T}_{6}$ during the year 2016-17 and treatment $\mathrm{T}_{12}$ during the year2017-18 was the best and recorded spike length $(113.50 \mathrm{~cm}$ and $107.50 \mathrm{~cm})$ respectively. Further, the data presented in table 3 revealed that interaction effect of different INM treatments and hybrids on spike length were found significant during both the year. During the first year, hybrid P16-1 x Eurovision had recorded the maximum spike length $(117.00 \mathrm{~cm})$ at treatment $\mathrm{T}_{6}$ while during second year, it was $115.00 \mathrm{~cm}$ spike length in hybrid Melody Open Seedling at treatment $\mathrm{T}_{12}$. Number of florets per spike was significantly influenced by treatment of organic, inorganic and bio fertilizers during the year 2016-17, 2017-18 and their mean. The maximum mean value of number of florets (16.33) was recorded in hybrid Melody Open Seedling during the first year and it was 17.66 florets per spike during the second year which was significantly higher than the other hybrid i.e. P-16-1 x Eurovision. Further, the treatment $\mathrm{T}_{6}$ i.e. application of $100 \% \mathrm{RDF}$ +@ 5 t/ha and mean of two hybrids was observed maximum 17.50 florets/spike during the year 2016-17 and it was maximum under treatment $\mathrm{T}_{8}$ and $\mathrm{T}_{12}$ during the year 2017-18; but it was minimum under control treatment during both the year. The interaction effect of organic, inorganic and bio fertilizers was also found significant on number of florets per spike during both the year and cleared from the data presented in table 4. Kumar et al., 2010 and Chouhan et al., 2014 found the maximum spike length with the application of higher doses of NPK and FYM i.e. $300 \mathrm{~kg} \mathrm{~N}$, $120 \mathrm{~kg} \mathrm{P}, 120 \mathrm{~kg} \mathrm{~K} / \mathrm{ha}+10 \mathrm{t} / \mathrm{ha} \mathrm{FYM}$. This might be due to greater uptake of nutrients into the plant system, which assured a rapid growth of stem by mobilization of nutrients toward the developing spikes. Similar beneficial effects of higher doses of primary nutrients on spike were reported by Lakshmi Durga et al., (2018).

Kumari et al., (2013) reported that application of 75 per cent RDF + VC (3 tonnes/ha) + VAM (10 kg/ha) + Azospirillum (10 kg/ha) + Trichoderma harzianum $(5 \mathrm{~kg} / \mathrm{ha})$ resulted in maximum plant height (116.28 and 118.60 $\mathrm{cm})$. minimum number of days taken for spike emergence (52.31 and 48.49) and number of days taken for first flower bud opening on a spike (58.74 and 54.56) in Rabi season. The photosynthetic system is activated for enhance biological efficiency, enabling synthesis of maximum metabolites and photosynthetes, thus encouraging quick 
growth which might be ultimately leads to increased plant height, length of spike and number of florets (Mageswari et al., 2013). Gaur et al., (2006) carried out an experiment in gladiolus and recorded maximum plant height $(108.50 \mathrm{~cm})$ with $75 \% \mathrm{NPK}+10$ tonnes/ha Vermicompost followed by $50 \%$ $\mathrm{NPK}+$ Vermicompost. The increased plant height at doses may be attributed to stimulatory action of sufficient supply of plant nutrients in terms of cell division and cell enlargement and the least determined height could be because of the unavailability of sufficient nutrients at critical crop stages for its luxuriant growth, these findings are supported with differential applications of NPK and FYM on number of florets (Khan and Ahmad, 2004).

The variation between the hybrids for marketable spikes and effect of different INM treatments and their interaction was observed significant during the year 2016-17 and 201718. During the first year, hybrid P-16-1 x Eurovision had produced 2.976 lakh spikes and during second year, the same hybrid produced 2.937 lakh spikes per hectare which was higher than the other hybrid i.e. Melody Open Seedling.

Examination of two year experimental finding showed that (Table 5) different treatment of organic, inorganic and bio fertilizers exerted significant effect on marketable spikes of gladiolus hybrids. The maximum mean value of two hybrids during both year was recorded under treatment $\mathrm{T}_{8}$ i.e. application of $125 \%$ RDF + Azospirillum + PSB followed by treatment $\mathrm{T}_{4}, \mathrm{~T}_{6}$ and $\mathrm{T}_{7}$ respectively (Table 5). In regard to interaction effect of INM treatment on marketable spikes/hectare and that was maximum under treatment $T_{7}$ with hybrid Melody Open Seedling and recorded 3.450 lakh spikes/ha during first year and 3.500 lakh per hectare during second year respectively.
From the table 6 , it was revealed between the hybrids that during first year and second year, mean value of corm per hectare was higher in Melody Open Seedling, but significantly at par with other hybrid P-16-1 x Eurovision. With respect to treatments and mean value of two hybrids, it was maximum under treatment $\mathrm{T}_{8}$ (3.700 lakh corms per hectare during first year) and treatment $\mathrm{T}_{4}$ (3.750 lakh corms per hectare during second year) as compared to remaining INM treatments. Further, the data presented in Table 6 revealed that interaction effect of organic, inorganic and bio fertilizers were also found significant on the number of corms per hectare during the year 2016-17 and 2017-18. Maximum number of corms (3.950 lakh/ha) was recorded during first year and during second year, it was again produced (4.00 lakh/ha corms) in hybrid Melody Open Seedling with the application of $125 \%$ RDF + Azospirillum +PSB.

The economics of different organic, inorganic and bio fertilizer treatments are usually a deciding factor for its adoption by the gladiolus growers for commercial spikes/corm production. It is, therefore, of wide interest to estimate and calculate the effects of various treatments on the number of corms production and to work out the most remunerative combination of these factors. The data (Table 7) and mean of two year study revealed that the treatment $\mathrm{T}_{4}$ i.e. application of FYM @ 10 t/ha resulted in the highest number of corms (3.712 lakh/ha) giving maximum gross income of Rs. 7.425 lakh/ha and net realization of Rs.4.225 lakh/ha and gave the highest CBR (1:2.32). The second best treatment combination in terms of corms production (3.700 lakh/ha and gross income Rs.7.400 lakh/ha), but it was third in net income and gave Rs.3.600 lakh/ha with the application of $125 \%$ RDF + Azospirillum +PSB . 
Table.1 Days to first flowering of gladiolus hybrids as influenced by different organic, inorganic and bio fertilizer treatments

\begin{tabular}{|c|c|c|c|c|c|c|c|}
\hline \multirow[t]{3}{*}{ S. N. } & \multirow[t]{3}{*}{ Treatments } & \multicolumn{6}{|c|}{ Days to first flowering } \\
\hline & & \multicolumn{3}{|c|}{ 2016-17 } & \multicolumn{3}{|c|}{$2017-18$} \\
\hline & & $\begin{array}{l}\text { Melody } \\
\text { Open } \\
\text { Seedling }\end{array}$ & $\begin{array}{l}\text { P-16-1 } \mathrm{x} \\
\text { Eurovision }\end{array}$ & Mean & $\begin{array}{l}\text { Melody Open } \\
\text { Seedling }\end{array}$ & $\begin{array}{l}\text { P-16-1 x } \\
\text { Eurovision }\end{array}$ & Mean \\
\hline 1 & $\mathrm{~T}_{1}:$ Control & 91.00 & 86.00 & 88.50 & 93.00 & 90.00 & 91.50 \\
\hline 2 & $\mathrm{~T}_{2}: 75 \% \mathrm{RDF}$ & 91.00 & 86.00 & 88.50 & 93.00 & 79.00 & 86.00 \\
\hline 3 & $\mathrm{~T}_{3}: 100 \%$ RDF (200:100:100 kg/ha NPK) & 91.00 & 87.00 & 89.00 & 84.00 & 98.00 & 91.00 \\
\hline 4 & $\mathrm{~T}_{4}: \mathrm{FYM} @ 10 \mathrm{t} / \mathrm{ha}$ & 91.00 & 84.00 & 87.50 & 90.00 & 86.00 & 88.00 \\
\hline 5 & $\mathrm{~T}_{5}:$ Vermicompost @10 t/ha & 90.00 & 85.00 & 87.50 & 90.00 & 86.00 & 88.00 \\
\hline 6 & $\mathrm{~T}_{6}: 100 \% \mathrm{RDF}+\mathrm{FYM} @ 5 \mathrm{t} / \mathrm{ha}$ & 84.00 & 85.00 & 84.50 & 92.00 & 92.00 & 92.00 \\
\hline 7 & $\begin{array}{l}\mathrm{T}_{7}: 100 \% \mathrm{RDF}+\text { Vermicompost } \\
\text { @ } 5 \mathrm{t} / \mathrm{ha}\end{array}$ & 84.00 & 85.00 & 84.50 & 96.00 & 90.00 & 93.00 \\
\hline 8 & $\begin{array}{l}\mathrm{T}_{8}: 125 \% \mathrm{RDF}+\text { Azospirillum } \\
+\mathrm{PSB}\end{array}$ & 91.00 & 86.00 & 88.50 & 93.00 & 92.00 & 92.50 \\
\hline 9 & $\begin{array}{l}\mathrm{T}_{9}: 75 \% \mathrm{RDF}+\mathrm{FYM} @ 10 \mathrm{t} / \mathrm{ha} \\
+ \text { Azospirillum + PSB }\end{array}$ & 90.00 & 87.00 & 88.50 & 96.00 & 80.00 & 88.00 \\
\hline 10 & $\begin{array}{l}\mathrm{T}_{10}: 75 \% \mathrm{RDF}+\text { Vermicompost @ } 10 \\
\mathrm{t} / \mathrm{ha} \\
+ \text { Azospirillum +PSB }\end{array}$ & 90.00 & 85.00 & 87.50 & 93.00 & 86.00 & 89.50 \\
\hline 11 & $\begin{array}{l}\mathrm{T}_{11}: 75 \% \mathrm{RDF}+\mathrm{FYM} @ 5 \mathrm{t} / \mathrm{ha} \\
+\quad \text { Vermicompost } @ 5 \text { t/ha }+ \\
\text { Azospirillum + PSB }\end{array}$ & 91.00 & 87.00 & 89.00 & 98.00 & 91.00 & 94.50 \\
\hline 12 & $\begin{array}{l}\mathrm{T}_{12}: 50 \% \mathrm{RDF}+\mathrm{FYM} @ 5 \mathrm{t} / \mathrm{ha} \\
\text { + Vermicompost @ } 5 \mathrm{t} / \mathrm{ha}+\text { liquid NPK }\end{array}$ & 91.00 & 86.00 & 88.50 & 92.00 & 92.00 & 92.00 \\
\hline & Mean & 89.58 & 85.75 & & 92.50 & 88.50 & \\
\hline & $\mathrm{CD}$ at $5 \%$, For hybrids & \multicolumn{2}{|c|}{2.31} & & \multicolumn{2}{|c|}{2.59} & \\
\hline & $\mathrm{CD}$ at $5 \%$, For treatments & \multicolumn{2}{|c|}{3.01} & & \multicolumn{2}{|c|}{2.99} & \\
\hline & $\mathrm{CD}$ at $5 \%$, For interaction & \multicolumn{2}{|c|}{3.28} & & \multicolumn{2}{|c|}{5.38} & \\
\hline
\end{tabular}


Table.2 Plant height of gladiolus hybrids as influenced by different organic, inorganic and bio fertilizer treatments

\begin{tabular}{|c|c|c|c|c|c|c|c|}
\hline \multirow[t]{3}{*}{ S. N. } & \multirow[t]{3}{*}{ Treatments } & \multicolumn{6}{|c|}{ Plant height (cm) } \\
\hline & & \multicolumn{3}{|c|}{ 2016-17 } & \multicolumn{3}{|c|}{$2017-18$} \\
\hline & & $\begin{array}{l}\text { Melody Open } \\
\text { Seedling }\end{array}$ & P-16-1 x Eurovision & Mean & $\begin{array}{l}\text { Melody Open } \\
\text { Seedling }\end{array}$ & P-16-1 x Eurovision & Mean \\
\hline 1 & $\mathrm{~T}_{1}$ & 99.00 & 110.00 & 104.50 & 95.00 & 80.00 & 87.50 \\
\hline 2 & $\mathrm{~T}_{2}$ & 120.00 & 125.00 & 122.50 & 102.00 & 88.00 & 95.00 \\
\hline 3 & $\mathrm{~T}_{3}$ & 123.00 & 108.00 & 115.50 & 117.00 & 100.00 & 108.50 \\
\hline 4 & $\mathrm{~T}_{4}$ & 121.00 & 108.00 & 114.50 & 109.00 & 92.00 & 100.50 \\
\hline 5 & $\mathrm{~T}_{5}$ & 106.00 & 102.00 & 104.00 & 120.00 & 89.00 & 104.50 \\
\hline 6 & $\mathrm{~T}_{6}$ & 122.00 & 127.00 & 124.50 & 102.00 & 90.00 & 96.00 \\
\hline 7 & $\mathrm{~T}_{7}$ & 110.00 & 100.00 & 105.00 & 107.00 & 110.00 & 108.50 \\
\hline 8 & $\mathrm{~T}_{8}$ & 109.00 & 110.00 & 109.50 & 122.00 & 95.00 & 108.50 \\
\hline 9 & $\mathrm{~T}_{9}$ & 110.00 & 100.00 & 105.00 & 102.00 & 100.00 & 101.00 \\
\hline 10 & $\mathrm{~T}_{10}$ & 95.00 & 102.00 & 98.50 & 102.00 & 92.00 & 97.00 \\
\hline 11 & $\mathrm{~T}_{11}$ & 100.00 & 110.00 & 105.00 & 95.00 & 88.00 & 91.50 \\
\hline \multirow[t]{5}{*}{12} & $\mathrm{~T}_{12}$ & 123.00 & 100.00 & 111.50 & 125.00 & 110.00 & 117.50 \\
\hline & Mean & 111.50 & 108.50 & & 108.16 & 94.50 & \\
\hline & $\mathrm{C} \mathrm{D}$ at $5 \%$, For varieties & \multicolumn{2}{|r|}{2.44} & & \multicolumn{2}{|r|}{4.30} & \\
\hline & $\begin{array}{l}\mathrm{C} \mathrm{D} \text { at } 5 \%, \text { For } \\
\text { treatments }\end{array}$ & \multicolumn{2}{|r|}{2.00} & & \multicolumn{2}{|r|}{5.96} & \\
\hline & $\begin{array}{l}\mathrm{C} \mathrm{D} \text { at } 5 \%, \text { For } \\
\text { interaction }\end{array}$ & \multicolumn{2}{|r|}{2.88} & & \multicolumn{2}{|r|}{2.65} & \\
\hline
\end{tabular}


Table.3 Spike length of gladiolus hybrids as influenced by different organic, inorganic and bio fertilizer treatments

\begin{tabular}{|c|c|c|c|c|c|c|c|}
\hline \multirow[t]{3}{*}{ S. $\mathbf{N}$. } & \multirow[t]{3}{*}{ Treatments } & \multicolumn{6}{|c|}{ Spike length $(\mathrm{cm})$} \\
\hline & & \multicolumn{3}{|c|}{ 2016-17 } & \multicolumn{3}{|c|}{$2017-18$} \\
\hline & & $\begin{array}{l}\text { Melody Open } \\
\text { Seedling }\end{array}$ & P-16-1 x Eurovision & Mean & $\begin{array}{l}\text { Melody Open } \\
\text { Seedling }\end{array}$ & P-16-1 x Eurovision & Mean \\
\hline 1 & $\mathrm{~T}_{1}$ & 88.00 & 100.00 & 94.00 & 85.00 & 70.00 & 77.50 \\
\hline 2 & $\mathrm{~T}_{2}$ & 110.00 & 115.00 & 112.50 & 92.00 & 78.00 & 85.00 \\
\hline 3 & $\mathrm{~T}_{3}$ & 113.00 & 98.00 & 105.50 & 107.00 & 90.00 & 98.50 \\
\hline 4 & $\mathrm{~T}_{4}$ & 110.00 & 98.00 & 104.00 & 99.00 & 82.00 & 90.50 \\
\hline 5 & $\mathrm{~T}_{5}$ & 96.00 & 90.00 & 93.00 & 110.00 & 79.00 & 94.50 \\
\hline 6 & $\mathrm{~T}_{6}$ & 110.00 & 117.00 & 113.50 & 92.00 & 80.00 & 86.00 \\
\hline 7 & $\mathrm{~T}_{7}$ & 100.00 & 90.00 & 95.00 & 97.00 & 90.00 & 93.50 \\
\hline 8 & $\mathrm{~T}_{8}$ & 98.00 & 100.00 & 99.00 & 112.00 & 85.00 & 98.50 \\
\hline 9 & $\mathrm{~T}_{9}$ & 100.00 & 90.00 & 95.00 & 92.00 & 90.00 & 91.00 \\
\hline 10 & $\mathrm{~T}_{10}$ & 84.00 & 92.00 & 88.00 & 92.00 & 82.00 & 87.00 \\
\hline 11 & $\mathrm{~T}_{11}$ & 90.00 & 100.00 & 95.00 & 85.00 & 78.00 & 81.50 \\
\hline \multirow[t]{5}{*}{12} & $\mathrm{~T}_{12}$ & 112.00 & 90.00 & 101.00 & 115.00 & 100.00 & 107.50 \\
\hline & Mean & 100.91 & 98.33 & & 98.16 & 83.66 & \\
\hline & $\mathrm{C} \mathrm{D}$ at $5 \%$, For varieties & \multicolumn{2}{|r|}{1.98} & & \multicolumn{2}{|r|}{2.83} & \\
\hline & $\begin{array}{l}\mathrm{C} \mathrm{D} \text { at } 5 \%, \text { For } \\
\text { treatments }\end{array}$ & \multicolumn{2}{|r|}{1.55} & & \multicolumn{2}{|r|}{3.76} & \\
\hline & $\begin{array}{l}\mathrm{CD} \text { at } 5 \%, \text { For } \\
\text { interaction }\end{array}$ & \multicolumn{2}{|r|}{2.25} & & \multicolumn{2}{|r|}{3.98} & \\
\hline
\end{tabular}


Table.4 Number of florets per spike of gladiolus hybrids as influenced by different organic, inorganic and bio fertilizer treatments

\begin{tabular}{|c|c|c|c|c|c|c|c|}
\hline \multirow[t]{3}{*}{ S. N. } & \multirow[t]{3}{*}{ Treatments } & \multicolumn{6}{|c|}{ Number of florets per spike } \\
\hline & & \multicolumn{3}{|c|}{ 2016-17 } & \multicolumn{3}{|c|}{$2017-18$} \\
\hline & & $\begin{array}{l}\text { Melody Open } \\
\text { Seedling }\end{array}$ & P-16-1 x Eurovision & Mean & $\begin{array}{l}\text { Melody Open } \\
\text { Seedling }\end{array}$ & P-16-1 x Eurovision & Mean \\
\hline 1 & $\mathrm{~T}_{1}$ & 14.00 & 14.00 & 14.00 & 14.00 & 12.00 & 13.00 \\
\hline 2 & $\mathrm{~T}_{2}$ & 17.00 & 15.00 & 16.00 & 18.00 & 11.00 & 14.50 \\
\hline 3 & $\mathrm{~T}_{3}$ & 16.00 & 15.00 & 15.50 & 18.00 & 12.00 & 15.00 \\
\hline 4 & $\mathrm{~T}_{4}$ & 18.00 & 14.00 & 16.00 & 18.00 & 10.00 & 14.00 \\
\hline 5 & $\mathrm{~T}_{5}$ & 14.00 & 13.00 & 13.50 & 19.00 & 11.00 & 15.00 \\
\hline 6 & $\mathrm{~T}_{6}$ & 18.00 & 17.00 & 17.50 & 16.00 & 12.00 & 14.00 \\
\hline 7 & $\mathrm{~T}_{7}$ & 15.00 & 13.00 & 14.00 & 16.00 & 14.00 & 15.00 \\
\hline 8 & $\mathrm{~T}_{8}$ & 16.00 & 15.00 & 15.50 & 20.00 & 14.00 & 17.00 \\
\hline 9 & $\mathrm{~T}_{9}$ & 17.00 & 12.00 & 14.50 & 17.00 & 14.00 & 15.50 \\
\hline 10 & $\mathrm{~T}_{10}$ & 17.00 & 12.00 & 14.50 & 18.00 & 12.00 & 15.00 \\
\hline 11 & $\mathrm{~T}_{11}$ & 16.00 & 12.00 & 14.00 & 18.00 & 13.00 & 15.50 \\
\hline \multirow[t]{5}{*}{12} & $\mathrm{~T}_{12}$ & 18.00 & 11.00 & 14.50 & 20.00 & 14.00 & 17.00 \\
\hline & Mean & 16.33 & 13.58 & & 17.66 & 12.41 & \\
\hline & $\mathrm{C} D$ at $5 \%$, For varieties & \multicolumn{2}{|r|}{1.08} & & \multicolumn{2}{|r|}{2.44} & \\
\hline & $\begin{array}{l}\mathrm{C} \mathrm{D} \text { at } 5 \%, \text { For } \\
\text { treatments }\end{array}$ & \multicolumn{2}{|r|}{0.99} & & \multicolumn{2}{|r|}{1.33} & \\
\hline & $\begin{array}{l}\mathrm{C} D \text { at } 5 \%, \text { For } \\
\text { interaction }\end{array}$ & \multicolumn{2}{|r|}{1.08} & & \multicolumn{2}{|r|}{1.55} & \\
\hline
\end{tabular}


Table.5 Number of marketable spike per hectare of gladiolus hybrids as influenced by different organic, inorganic and bio fertilizer treatments

\begin{tabular}{|c|c|c|c|c|c|c|c|}
\hline \multirow[t]{3}{*}{ S. $\mathbf{N}$. } & \multirow[t]{3}{*}{ Treatments } & \multicolumn{6}{|c|}{ Number of marketable spikes (Lakh/ha.) } \\
\hline & & \multicolumn{3}{|c|}{ 2016-17 } & \multicolumn{3}{|c|}{$2017-18$} \\
\hline & & $\begin{array}{l}\text { Melody Open } \\
\text { Seedling }\end{array}$ & P-16-1 x Eurovision & Mean & $\begin{array}{l}\text { Melody Open } \\
\text { Seedling }\end{array}$ & P-16-1 x Eurovision & Mean \\
\hline 1 & $\mathrm{~T}_{1}$ & 2.420 & 2.800 & 2.610 & 2.400 & 2.775 & 2.587 \\
\hline 2 & $\mathrm{~T}_{2}$ & 1.800 & 3.000 & 2.400 & 1.850 & 3.075 & 2.462 \\
\hline 3 & $\mathrm{~T}_{3}$ & 3.100 & 3.200 & 2.860 & 3.150 & 2.600 & 2.875 \\
\hline 4 & $\mathrm{~T}_{4}$ & 3.000 & 3.150 & 3.100 & 3.200 & 3.175 & 3.187 \\
\hline 5 & $\mathrm{~T}_{5}$ & 2.800 & 3.250 & 2.975 & 2.850 & 3.100 & 2.975 \\
\hline 6 & $\mathrm{~T}_{6}$ & 3.100 & 2.900 & 3.175 & 3.000 & 3.100 & 3.050 \\
\hline 7 & $\mathrm{~T}_{7}$ & 3.450 & 3.300 & 3.175 & 3.500 & 2.850 & 3.175 \\
\hline 8 & $\mathrm{~T}_{8}$ & 3.405 & 2.900 & 3.352 & 3.400 & 3.250 & 3.325 \\
\hline 9 & $\mathrm{~T}_{9}$ & 2.800 & 2.800 & 2.850 & 2.750 & 2.725 & 2.737 \\
\hline 10 & $\mathrm{~T}_{10}$ & 2.100 & 2.850 & 2.450 & 2.075 & 2.750 & 2.412 \\
\hline 11 & $\mathrm{~T}_{11}$ & 3.100 & 2.950 & 2.975 & 3.000 & 2.800 & 2.900 \\
\hline \multirow[t]{5}{*}{12} & $\mathrm{~T}_{12}$ & 2.850 & 2.976 & 2.900 & 2.750 & 3.050 & 2.900 \\
\hline & Mean & 2.827 & & & 2.827 & 2.937 & \\
\hline & $\mathrm{C} \mathrm{D}$ at $5 \%$, For varieties & \multicolumn{2}{|c|}{0.100} & & \multicolumn{2}{|r|}{0.100} & \\
\hline & $\begin{array}{l}\mathrm{C} \mathrm{D} \text { at } 5 \%, \text { For } \\
\text { treatments }\end{array}$ & \multicolumn{2}{|c|}{0.348} & & \multicolumn{2}{|r|}{0.405} & \\
\hline & $\begin{array}{l}\mathrm{C} \mathrm{D} \text { at } 5 \%, \text { For } \\
\text { interaction }\end{array}$ & \multicolumn{2}{|c|}{0.700} & & \multicolumn{2}{|r|}{0.450} & \\
\hline
\end{tabular}


Table.6 Number of corms per hectare of gladiolus hybrids as influenced by different organic, inorganic and bio fertilizer treatments

\begin{tabular}{|c|c|c|c|c|c|c|c|}
\hline \multirow[t]{3}{*}{ S. N. } & \multirow[t]{3}{*}{ Treatments } & \multicolumn{6}{|c|}{ Number of corms (Lakh/ha.) } \\
\hline & & \multicolumn{3}{|c|}{ 2016-17 } & \multicolumn{3}{|c|}{$2017-18$} \\
\hline & & $\begin{array}{l}\text { Melody Open } \\
\text { Seedling }\end{array}$ & P-16-1 x Eurovision & Mean & $\begin{array}{l}\text { Melody Open } \\
\text { Seedling }\end{array}$ & P-16-1 x Eurovision & Mean \\
\hline 1 & $\mathrm{~T}_{1}$ & 2.950 & 2.900 & 2.925 & 2.975 & 2.850 & 2.912 \\
\hline 2 & $\mathrm{~T}_{2}$ & 2.960 & 3.150 & 3.055 & 3.000 & 3.100 & 3.050 \\
\hline 3 & $\mathrm{~T}_{3}$ & 3.200 & 2.900 & 3.050 & 3.375 & 2.875 & 3.125 \\
\hline 4 & $\mathrm{~T}_{4}$ & 3.850 & 3.500 & 3.675 & 3.925 & 3.575 & 3.750 \\
\hline 5 & $\mathrm{~T}_{5}$ & 3.300 & 3.750 & 3.525 & 3.225 & 3.625 & 3.425 \\
\hline 6 & $\mathrm{~T}_{6}$ & 3.300 & 3.360 & 3.330 & 3.375 & 3.350 & 3.362 \\
\hline 7 & $\mathrm{~T}_{7}$ & 3.720 & 2.900 & 3.310 & 3.750 & 2.850 & 3.300 \\
\hline 8 & $\mathrm{~T}_{8}$ & 3.950 & 3.450 & 3.700 & 4.000 & 3.400 & 3.700 \\
\hline 9 & $\mathrm{~T}_{9}$ & 3.000 & 3.600 & 3.300 & 2.925 & 3.550 & 3.237 \\
\hline 10 & $\mathrm{~T}_{10}$ & 2.800 & 3.100 & 2.950 & 2.675 & 3.000 & 2.837 \\
\hline 11 & $\mathrm{~T}_{11}$ & 3.150 & 3.350 & 3.250 & 3.050 & 3.400 & 3.225 \\
\hline \multirow[t]{5}{*}{12} & $\mathrm{~T}_{12}$ & 3.200 & 3.400 & 3.300 & 3.075 & 3.325 & 3.200 \\
\hline & Mean & 3.281 & 3.280 & & 3.279 & 3.241 & \\
\hline & $\mathrm{C} \mathrm{D}$ at $5 \%$, For varieties & \multicolumn{2}{|c|}{ NS } & & \multicolumn{2}{|r|}{0.035} & \\
\hline & $\begin{array}{l}\mathrm{C} \mathrm{D} \text { at } 5 \%, \text { For } \\
\text { treatments }\end{array}$ & \multicolumn{2}{|c|}{0.382} & & \multicolumn{2}{|r|}{0.488} & \\
\hline & $\begin{array}{l}\mathrm{CD} \text { at } 5 \%, \text { For } \\
\text { interaction }\end{array}$ & \multicolumn{2}{|c|}{1.180} & & \multicolumn{2}{|r|}{0.245} & \\
\hline
\end{tabular}


Table.7 Number of corms, gross and net returns of gladiolus hybrids per hectare as influenced by different organic, inorganic and bio fertilizer treatments

\begin{tabular}{|c|c|c|c|c|c|c|}
\hline S. $\mathbf{N}$. & Treatments & $\begin{array}{l}\text { Number of corms } \\
\text { (Lakh/ha.) } \\
\text { Mean of two year of } \\
\text { both the hybrids }\end{array}$ & $\begin{array}{l}\text { Total gross returns } \\
\text { (Rs lakh/ha) } \\
\text { Mean of two year of } \\
\text { both the hybrids }\end{array}$ & $\begin{array}{l}\text { Total cost of production. } \\
\text { (Rs. lakh/ha) } \\
\text { Mean of two year of } \\
\text { both the hybrids }\end{array}$ & $\begin{array}{l}\text { Net returns (Rs lakh/ha) } \\
\text { Mean of two year of both } \\
\text { the hybrids }\end{array}$ & $\begin{array}{c}\text { Benefit cost } \\
\text { ratio (Rs.) }\end{array}$ \\
\hline 1 & $\mathrm{~T}_{1}$ & 2.918 & 5.837 & 3.100 & 2.737 & $1: 1.88$ \\
\hline 2 & $\mathrm{~T}_{2}$ & 3.052 & 6.105 & 3.050 & 3.055 & $1: 2.01$ \\
\hline 3 & $\mathrm{~T}_{3}$ & 3.087 & 6.175 & 3.070 & 3.105 & $1: 2.01$ \\
\hline 4 & $\mathrm{~T}_{4}$ & 3.712 & 7.425 & 3.200 & 4.225 & $1: 2.32$ \\
\hline 5 & $\mathrm{~T}_{5}$ & 3.475 & 6.950 & 3.300 & 3.650 & $1: 2.10$ \\
\hline 6 & $\mathrm{~T}_{6}$ & 3.346 & 6.692 & 3.115 & 3.577 & $1: 2.14$ \\
\hline 7 & $\mathrm{~T}_{7}$ & 3.305 & 6.610 & 3.170 & 3.440 & $1: 2.08$ \\
\hline 8 & $\mathrm{~T}_{8}$ & 3.700 & 7.400 & 3.800 & 3.600 & $1: 1.94$ \\
\hline 9 & $\mathrm{~T}_{9}$ & 3.268 & 6.537 & 3.900 & 2.637 & $1: 1.67$ \\
\hline 10 & $\mathrm{~T}_{10}$ & 2.893 & 5.787 & 3.950 & 1.837 & $1: 1.46$ \\
\hline 11 & $\mathrm{~T}_{11}$ & 3.237 & 6.475 & 3.980 & 2.495 & $1: 1.62$ \\
\hline 12 & $\mathrm{~T}_{12}$ & 3.250 & 6.500 & 3.200 & 3.300 & $1: 2.03$ \\
\hline
\end{tabular}


The next best treatment combination which had recorded Rs.3.650 lakh/ha net return with the application of Vermicompost @10 t/ha, whereas, it was minimum under treatment $\mathrm{T}_{10}$ as compared to other remaining treatments. Gangadharan and Gopinath (2000) worked on gladiolus and reported that combination of 10 tonnes $\mathrm{ha}^{-1}$ Vermicompost+ $80 \%$ NPK resulted in the maximum number of corms ( 6.820 lakh/ha), highest benefit: cost ratio (1.56: 1), gross (Rs 13, 16,400) and net income(Rs 8, 01,779.03). In a field trial conducted by Karthiresan and Venkatesh in 2002 at GKVK, Bangalore, reported that gladiolus cv. White Prosperity produced maximum plant height with the application of Azospirillum and VAM along with recommended dose and 25\% (75:45:60 kg/ha) reduced dose of NPK. Further, they reported and found that best combination was $25 \%$ reduced dose of NPK i.e.75:45:60 kg NPK/ha+ Azospirillum + VAM. Singhet al., (2008) worked on gladiolus and reported that maximum plant height, spike length. Number of floret per spike, were recorded when Vermicompost@10 t ha ${ }^{-1}$ and bio-fertilizers namely Azospirillum and VAM and PSB were applied. Mageswari et al., 2013 reported further that treatment received $50 \%$ of RDF+FYM $\left(2 \mathrm{~kg} / \mathrm{m}^{2} /\right.$ year $)+$ Vermicompost $\left(300 \mathrm{~g} / \mathrm{m}^{2}\right)+$ Azospirillum (2 g /plant $)+$ PSB ( $2 \mathrm{~g} /$ plant) was found to be good with respect to vegetative and floral characters. Kumar et al., (2011) also reported that maximum plant height $(101.2 \mathrm{~cm})$, spike length $(88.2 \mathrm{~cm})$ and number of florets per spike (14.4) was found maximum with the treatment i.e. $(\mathrm{CBD}+$ Vermicompost 5 tonnes/ha). In an investigation conducted by Madinat-ul- Nisa et al.,(2016) reported the response of integrative nutrient application in gladiolus cv. Priscilla and found significant differences amongst all the treatments. The results endorsed that the treatment $\mathrm{T}_{6}$ (Azotobacter 1 litre/10 kg + Azospirillium 1 litre/10 kg + $80 \% \mathrm{~N}+100 \% \mathrm{PK})$ significantly improved the number of florets per spike (14.20), number of spikes per $\mathrm{m}^{2}$ (32.00), corms per $\mathrm{m}^{2}$ (74.70). This may be due to the combined action of bio fertilizers and inorganic fertilizers, which resulted in more assimilation of photosynthates towards sink, and there by increased the yield characters. The results of present investigation are close agreement and conformity with the findings of above mentioned workers.

In conclusions, the results of two year study showed that in and around Delhi condition, the application of organic, inorganic and bio fertilizers had produced significant effect on vegetative and corm production parameters viz., days to first flowering, plant height, spike length, number of florets per spike, number of marketable spikes and number of corms per hectare. Maximum number of corms was produced in hybrid Melody Open Seedling with the application of $125 \%$ RDF + Azospirillum +PSB, and treatment $\mathrm{T}_{4}$ i.e. application of FYM @ 10 t/ha resulted in the highest number of corms (3.712 lakh/ha) giving maximum gross income of Rs. 7.425 lakh/ha and net realization of Rs.4.225 lakh/ha and gave the highest CBR (1:2.32).

\section{References}

Barman, D., Rajni, K., Rampal., Upadhyaya, R.C. 2005. Corm multiplication of gladiolus as influenced by application of potassium and spike removal. Journal of ornamentalHorticulture,8 (2): 104-107.

Chouhan, P., Sankar, U.M., Rathore, V. 2014. Effect of NPK on physico- chemical parameters of gladiolus cv. White Prosperity. International Journal of Science Research Publication, 4:1-5

Gangadharan, G. D., Gopinath, G. 2000. Effects of organic and inorganic fertilizerson yield of spikes, corms, cormels and returns of gladiolus cv. White Prosperity. Karnataka Journal of Agricultural Sciences., 13(4): 937941.

Gaur, A., Misra, R.L., Kumar, P.N., Sarkar, J. 
2006. Studies on nutrient management in gladiolus. Paper presented in the "National Symposium on Ornamental Bulbous Crops" held on 5-6 December, 2006 at S.V.B.P.U. of Ag. \& T., Modipuram, Meerut (U.P.): 107.

Kanaujia, S.P., Tzudir, Alongba., Maiti, C.S., Sentimenla 2018. Effect of integrated nutrient management on growth, yield and quality of turmeric under Nagaland conditions. Indian Journal of Horticulture, 75(1): 92-98.

Karthiresan, C., Venkatesh, J. 2002. Effect of biofertilizers with levels of $\mathrm{N}$ and $\mathrm{P}$ on gladiolus. In: Floriculture Research Trend in India (editors: R.L. Misra and Sanyat Misra), Indian Society of Ornamental Horticulture, 118-121.

Khan, M.A., Ahmad, I., 2004. Growth and flowering of gladiolus (Gladiolus hortulanus L.) cv. Wind Song as influenced by various levels of NPK. International Journal of Agriculture Biology, 6:1037-39.

Kumar, R., D. S. Yadav, 2005. Evaluation of gladiolus cultivars under sub-tropical hills of Meghalaya. Journal ornamentalHorticulture,8 (2): 86-90.

Kumar, R., Misra, R.L., Singh, S.K. 2010. Postharvest life of gladiolus cv. Jester Gold as influenced by different doses of nitrogen, phosphorus and potassium. Indian Journal of Horticulture, 67(Special issue):399-402.

Kumar, R., Kumar, R., Kumar, P. 2011. Effect of integrated use of chemical fertilizers, biofertilizers and bio-stimulants in gladiolus (Gladiolus grandiflorus L.) cv. Sancerre. Progressive Horticulture, 43(1): 149-152.

Kumari, R.V., Kumar, D.P., Mahadevamma, M., Arunkumar, B. 2013. Effect of integrated nutrient management on growth and floral parameters in gladiolus (Gladiolus hybridus L.) cv. American beauty. The Asian Journal of Horticulture, 8(1): 274-279.

Lakshmi Durga, M., Raju, D.V.S., Pandey, R.N.,
Pandey Renu., Kumar, Prabhat., Singh, Kan. P., Gopal Krishnan, S. 2018. Integrated use of NPK fertilizer with FYM influences growth, floral attributes, soil fertility and nutrient uptake of gladiolus in an Incetisol of semiarid tropics. Indian Journal of Horticulture, 75(1): 119-123.

Lepcha, B., Nautiyal, M. C., Rao, V. K. 2007. Variability studies in gladiolus under mid hill conditions of Uttarakhand. Journal of Ornamental Horticulture, 10(3): 169-172.

Mageswari, N., Arulmozhiyam, R., Sankar, A., Anand, M., Durga Devi, M. 2013. Integrated nutrient management in gladiolus under Eastern ghat conditions. Journal of Ornamental Horticulture, 16(1\&2): 15-18.

Madinat-ul-Nisa., K.M Malik., Z.A. Rather. 2016. Effect of bio fertilizers on growth, flowering and corm yield in Gladiolus (Tourn.) L. cv. Priscilla. Green Farming, 7(5): 1256-1259.

Panse, V.G., P.V. Shukhatme. 1967. Statistical Methods for Agricultural Workers, ICAR, Krishi Bhawan, New Delhi.

Singh, B. R., Gaurav, S. B., Katwate, S. M., Chaudhary, S. M., Kakade, D. S., Patil, M. T. 2006. Integrated nutrient management in gladiolus. "National Symposium on Ornamental Bulbous Crops". Held on 5-6 December, 2006 at S.V.B.P.U. of Ag. \& T., Modipuram, Meerut (U.P.): 66.

Singh, D. P., Prakash, S.,Singh, A. P. 2008. Response of vermicompost and bio-fertilizer on growth and flowering in gladiolus cv. Red Beauty. National Symposium on Recent Advances in Indian Floriculture: 69.

Wani, Muneeb Ahmad., Sartaj A. Wani., Ahmad, Malik Sajad., Riaz Ahmed Lone, Gazanfer Gani, Khan, F.U., Neelofar. 2017. Integrated Nutrient Management (INM) Approaches in Flower Crops. International Journal of Current Microbiology and Applied Sciences. 6(3): 254-265.

\section{How to cite this article:}

Kishan Swaroop and Sharma, V.K. 2020. Impact of Organic and Inorganic Nutrient Management Practices on Flowering, Corm Traits and Profitability of Gladiolus Hybrids. Int.J.Curr.Microbiol.App.Sci. 9(08): 3525-3538. doi: https://doi.org/10.20546/ijcmas.2020.908.407 